\title{
Determination of optimal conditions for laccase production by Pleurotus ostreatus using sawdust as solid medium and its use in phenol degradation
}

\author{
Abdulkareem jasim Hashim* \\ Received 24, April , 2011 \\ Accepted 26, September, 2011
}

\begin{abstract}
:
The ability of four local fungal isolates for extracellular laccase production has been tested with five grams 1:1(w/v) humidified sawdust as substrate in mineral salt medium. After 21 day of incubation at $25 \pm 1{ }^{\circ} \mathrm{C}$ and using one mycelial plug $(5 \mathrm{~mm})$, higher level of laccase activity $(0.15 \mathrm{U} / \mathrm{ml})$ and specific activity $(15 \mathrm{U} / \mathrm{mg})$ were observed by Pleurotus ostreatus in comparison with other fungal isolates. The results of optimum conditions for laccase production from selected isolate showed that, the maximum laccase activity $(0.55 \mathrm{U} / \mathrm{ml})$ and specific activity $(55 \mathrm{U} / \mathrm{mg})$ were obtained at moisture ratio $1: 3(\mathrm{w} / \mathrm{v})$, using 3 mycelial plugs $(5 \mathrm{~mm})$, after 15 days incubation period at $25 \pm 1{ }^{\circ} \mathrm{C}$. The results of phenol degradation by crud laccase revealed that, $100 \%$ degradation of phenol occurred after $24 \mathrm{hr}$ of incubation at $25^{\circ} \mathrm{C}$ using shaking water bath except at $200 \mathrm{mg} / 1$, the remaining phenol was $10.13 \%$.
\end{abstract}

Key words: Sawdust, laccase, Pleurotus ostreatus, optimization, biodegradation.

\section{Introduction:}

Enzyme production is an important field in Biotechnology. Most enzyme manufacturers produce enzymes by submerged fermentation (SmF) techniques. However, in the last decades there has been an increasing trend towards the use of the solid-state fermentation (SSF) technique to produce several enzymes. A direct comparison between SSF and SmF cultivation techniques is difficult to make because the two processes are quite different. Studies on fungal enzyme production in SSF have shown that SSF, in comparison with SmF, provides higher volumetric productivities, is less prone to problems with substrate inhibition and yields enzymes at a higher temperature or $\mathrm{pH}$ stability [1].

Laccase (E.C. 1.10.3.2) is the most common ligninmodifying enzyme produced by the white-rot fungi belonging to the family Polyporaceae [2]. Among them, Trametes versicolor has extensively been used as the main experimental organism for laccase production studies [3]. Most studies dealing with ligninolytic enzyme production by white-rot fungi have been carried out using the liquid culture conditions, in spite of the fact that these organisms grow in nature in solid-state conditions. Recent reviews on solid-state fermentation (SSF) point out the enormous potential of this culture technique for the development of different bioprocesses [4]. The selection of a substrate for SSF processes depends upon several factors mainly related with cost and availability and thus may involve screening of several agro-industrial residues. Moreover, the utilization of this type of supports helps to solve the pollution problems caused by their

*Biotechnology Department, College of Science, Baghdad University 
disposal. The potential use of laccases in biotechnology has stimulated the need to discover suitable enzymes in large quantities. Laccase production may be affected by fermentation factors such as, fungal isolate, medium composition, $\mathrm{pH}$, temperature and aeration. There have been reports describing increased production of extracellular laccases in many species of white rot fungi when grown on natural substrates, such as cotton stalk [5], molasses waste water [6], wheat bran [7] and barley bran [8]. Utilization of industrial and agricultural wastes for laccase production is an effective way to reduce production costs and also simultaneously utilize these substrates efficiently [9]. Laccase has been intensively investigated because of its ability to degrade biopolymeric structures and usefulness in the synthesis of organic compounds [10]. The current work aims to select the optimal conditions for laccase production from local fungal isolates using sawdust as substrate and its role in phenol degradation.

\section{Materials and methods : Fungal isolates}

The isolates Trichoderma sp. and Rhizoctonia solani were obtained from Department of Biology, while Fusarium sp. and Pleurotus ostreatus were obtained from Department of Biotechnology, College of Science, Baghdad University. All fungal isolates were cultivated at $25 \pm 1^{\circ} \mathrm{C}$ on potato dextrose agar (PDA) and stored at $4^{\circ} \mathrm{C}$.

\section{Laccase production on solid substrate}

Solid-substrate fermentation (SSF) medium consists of $5 \mathrm{gm}$ sawdust has been used for producing the fungal enzymes. The substrate was humidified with a $5 \mathrm{ml} \mathrm{w} / \mathrm{v}$ of mineral salt solution containing $(0.2 \mathrm{~g}$ $\mathrm{KH} 2 \mathrm{PO} 4, \quad 0.1 \mathrm{~g} \quad \mathrm{MgSO} 4.7 \mathrm{H} 2 \mathrm{O}, \quad 0.3 \mathrm{~g}$ $\mathrm{NH} 4 \mathrm{Cl} 2,1.0 \mathrm{~g} \mathrm{CaCO} 3$ in $1 \mathrm{~L}$ distilled water $\mathrm{pH}$, 5.3). The humidified medium was placed in $250 \mathrm{ml}$ Erlenmeyer flasks and autoclaved at $\left(121^{\circ} \mathrm{C}, 20 \mathrm{~min}\right)$. The sterilized medium was inoculated with one mycelial plug $(5 \mathrm{~mm})$ from 7-day-old cultures of Trichoderma sp., $R$. solani, Fusarium sp. and $P$. ostreatus separately (two flasks for each isolate). Then the flasks were incubated for 21 days at $25 \pm 1^{\circ} \mathrm{C}$ [11]. Flasks without inoculation were used as control.

\section{Enzyme extraction:}

Laccase was extracted from sawdust culture using $50 \mathrm{ml}(1: 10 \mathrm{w} / \mathrm{v})$, of $0.1 \mathrm{M}$ cooled citrate-phosphate buffer, $\mathrm{pH}$ 5.6. The contents of the flasks were grind in a mortar for $30 \mathrm{~min}$ in ice bath. The crud extracts were filtered through gauze, and then centrifuged at $6000 \mathrm{rpm}$ for $15 \mathrm{~min}$ using cooled centrifuge [12].

\section{Enzyme and protein assays}

Laccase activity was followed spectrophotometrically at $525 \mathrm{~nm}$, through the oxidation of syringaldazine to its quinone form, using a molar absorptivity of 65,000 for the product [13]. The reaction mixture contained 2 $\mathrm{ml}$ citrate- phosphate buffer $(0.1 \mathrm{M}$, $\mathrm{pH}$ 5.6), $0.2 \mathrm{ml}$ syringaldazine (0.5 $\mathrm{mM}$ in methanol solution), and $1 \mathrm{ml}$ of culture filtrates. The enzymatic activities were expressed as international units (U), defined as the amount of enzyme required to produce $1 \mu \mathrm{mol} \quad$ product $/ \mathrm{min}$. Protein concentrations were determined using standard curve of bovine serum albumin [14]. 
Effect of cultural conditions on laccase production:

- Moisture ratio:

Mineral salt solution was added to the $5 \mathrm{~g}$ sawdust at different ratio 1:1, 1:2, $1: 3$ and 1:4 w/v. The humidified medium was placed in $250 \mathrm{ml}$ Erlenmeyer flasks and autoclaved $\left(121^{\circ} \mathrm{C}, 20 \mathrm{~min}\right)$. The autoclaved medium was inoculated with one mycelial plug $(5 \mathrm{~mm})$ from 7 -day-old cultures of $P$. ostreatus (two flasks for each moisture ratio). The flasks were incubated for 21 days at $25 \pm 1^{\circ} \mathrm{C}$. Flasks without inoculation were used as control.

\section{- Incubation period:}

Mineral salt solution has been added to the $5 \mathrm{~g}$ sawdust at ratio 1:3 (w/v). The humidified medium was placed in $250 \mathrm{ml}$ Erlenmeyer flasks and autoclaved $\left(121^{\circ} \mathrm{C}, 20 \mathrm{~min}\right)$. The sterilized medium was inoculated with one mycelial plug $(5 \mathrm{~mm})$ from 7-dayold cultures of $P$. ostreatus (two flasks for each incubation period). The flasks were incubated for $5,8,15,18,21$, and 25 days at $25 \pm 1^{\circ} \mathrm{C}$. Flasks without inoculation were used as control.

- Inoculum size:

Same medium above has been used with different inoculums size of 1,2, 3 , and 4 mycelial plugs $(5 \mathrm{~mm})$ from $7-$ day-old cultures of $P$. ostreatus (two flasks for each inoculum size). The flasks were incubated for 15 days at $25 \pm 1^{\circ}$ C. Flasks without inoculation were used as control.

\section{- Incubation temperature:-}

To determine the effect of incubation temperatures in laccase production, $5 \mathrm{~g}$ of sawdust with moisture ratio 1:3 have been inoculated with 3 mycelial plugs $(5 \mathrm{~mm})$. The flasks were incubated for 15 day at 20, 25, 28, 30, and $37^{\circ} \mathrm{C}$, (two flasks for each incubation temperatures). Flasks without inoculation were used as control.

\section{- Biodegradation of phenol by crud enzyme:}

The oxidation of standard phenol by crud enzyme has been performed by mixing $1 \mathrm{ml}$ enzyme filtrate with $2 \mathrm{ml}$ of $0.1 \mathrm{M}$ citrate-phosphate buffer $(\mathrm{pH}$, 5.6) at different phenol concentrations $(6.25,12.5,25,50,100$, and 200 $\mathrm{mg} / \mathrm{l})$. The mixture was incubated at $25^{\circ}$ $\mathrm{C}$ in shaking water bath. The percent (\%) of phenol degradation was calculated after zero, 2, 4, 6, and $24 \mathrm{hr}$ according to the following equation:

Phenol concentration after incubation at different times x 100

Phenol degradation $(\%)=$

\section{Phenol concentration at zero time}

\section{Results and discussion:}

- Laccase production from fungal isolates on solid state fermentation:

In general five grams of sawdust humidified with mineral salt solution $(1: 1)(w / v)$ has been used as solid medium for laccase production from four fungal isolates. Results in (Tab.1) indicated that, the highest level of laccase production was obtained from $P$. ostreatus; laccase activity was 0.15 $\mathrm{U} / \mathrm{ml}$ with specific activity $15 \mathrm{U} / \mathrm{mg}$. Other fungal isolates seem to be as a weak laccase producers, laccase activities were $0.02,0.03$ and 0.05 U/ml from Trichoderma sp., Fusarium sp., and Rhizoctonia solani respectively. However, [15] found that, a very low activity $(0.005 \mathrm{U} / \mathrm{ml})$ and high protein concentration $(0.387$ $\mathrm{mg} / \mathrm{ml}$ ) were observed when $\mathrm{SmF}$ was used to produce laccase from $P$. ostreatus. In current study, high level of laccase activity observed by using sawdust as substrate due to presence of 
lignin as the main component of this waste which serve as enzyme inducer.

Solid state fermentation possesses several biological advantages as compared with submerged fermentations. Such advantages include higher fermentation productivity, less catabolic repression, low water demand and hence, lower sterility demand due to the low water activity [16]. However, the most suitable condition for maximum production of Pleurotus pulmonarius laccase $(8,600 \mathrm{U} / \mathrm{g}$ substrate $)$ was at initial moisture content of $75 \%$ in 5 days cultivation at $30{ }^{\circ} \mathrm{C}$ using syringaldazine as substrate [7].

The ability of various white-rot fungi for laccase production has been studied using different cereal crop wastes as substrate, for example, maximum laccase activity $(68 \mathrm{U} / \mathrm{ml})$ was obtained with $P$. ostreatus at $8^{\text {th }}$ days of fermentation on wheat straw using (2,2_-azinodi-[3-ethyl-benzo-thiazolinsulphonate]) ABTS as substrate for laccase activity assay [17]. On the other hand rice straw was identified as a suitable substrate for laccase production(17.3U/g)from Streptomyces psammoticus [18].

Table 1: Laccase production from different fungal isolates on humidified sawdust Medium.

\begin{tabular}{|c|c|c|c|}
\hline Fungal isolate & $\begin{array}{c}\text { Laccase } \\
\text { activity } \\
\text { U/ml }\end{array}$ & $\begin{array}{c}\text { Protein } \\
\text { con. } \\
\mathbf{m g} / \mathbf{m l}\end{array}$ & $\begin{array}{c}\text { Specific } \\
\text { activity } \\
\text { U/mg }\end{array}$ \\
\hline Trichoderma $s p$. & 0.02 & 0.015 & 1.33 \\
\hline Fusarium $s p$. & 0.03 & 0.032 & 0.94 \\
\hline Rhizoctonia solani & 0.05 & 0.017 & 2.94 \\
\hline Pleurotus ostreatus & 0.15 & 0.010 & 15 \\
\hline
\end{tabular}

Effect of moisture ratio on $P$. ostreatus laccase production:

Moisture is another key parameter to control the growth of microorganism and metabolite production in SSF. In present work, Five grams of sawdust has been humidified by mineral solution with different moisture ratio $(1: 1,1: 2,1: 3$, and 1:4 (w/v). Laccase production was increased with increasing the ratio of moisture reached up to $0.27 \mathrm{U} / \mathrm{ml}$ with $1: 3$ moisture ratios and then decreased (Fig, 1).

Higher initial moisture in SSF leads to suboptimal product formation due to reduced mass transfer, while decrease in initial moisture level results in reduced solubility and low availability of nutrients to the culture. [18] observed optimum laccase production by $S$. psammoticus at initial moisture content of $65 \%$.

Sawdust is comparatively a dry substrate and hence a low initial moisture level was observed to be inadequate for moistening the substrate evenly. However increasing the initial moisture content above the optimum also resulted in decreased enzyme yield, and this may be due to the reduction in interparticle space and decreased porosity. Humidified grape seeds and barley bran with moisture ratios (1:3 and 1:6) were used to produce laccase from Trametes hirsute, barley bran led to the highest activity levels reaching maximum values of about $1.2 \mathrm{kUl}^{-1} 1$ [19]. While, maximum laccase activity 40U/g obtained using wheat straw with moisture ratio $1: 4$ by Fusarium incarnatum LD-3, amongst the forty one isolates tested [20].

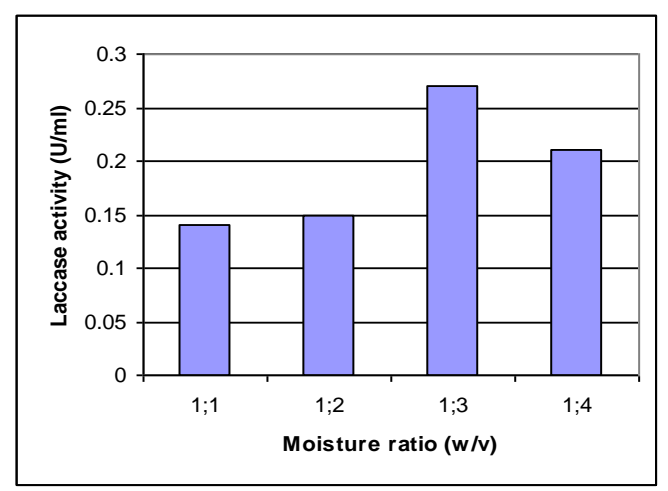

Fig 1: Effect of moisture ratio (w/v) in laccase production by Pleurotus ostreatus on humidified sawdust medium. 
- Effect of incubation period on $P$. ostreatus laccase production:

The effect of incubation period on $P$. ostreatus laccase production has been studied. Maximum level of laccase activity $(0.395 \mathrm{U} / \mathrm{ml})$ was observed after 15 days of incubation (Fig,2) and specific activity was increased up to $39.5 \mathrm{U} / \mathrm{mg}$ (results are not showen). And no activity was observed even after 25 days of incubation. However, other investigator found high level of $P$. ostreatus laccase production $(68 \mathrm{U} / \mathrm{ml})$ at $8^{\text {th }}$ days of incubation, when wheat straw was used as substrate [17]. Different pattern in production of laccase was found with several white- and brown rot fungi cultivated on Eucalyptus grandis wood chips. Trametes versicolor produced the highest xylenase and cellulase from solid state culture at 15 days, while maximum laccase and peroxidase production were obtained until 60 days of incubation [21].

- Effect of inoculm size on $P$. ostreatus laccase production:

Different mycelial plugs $(1,2,3$, and 4 $\times 5 \mathrm{~mm})$ of $P$. ostreatus fungal isolate have been used. Laccase activity and protein concentration were determined after 15 day of incubation at $25 \pm 1^{\circ} \mathrm{C}$. Highest level of laccase activity was obtained by using 3 mycelia plugs as inoculum, laccase activity was $0.55 \mathrm{U} / \mathrm{ml}$ with specific activity $55 \mathrm{U} / \mathrm{mg}$ (results are not shown). After the same incubation period (15 days) laccase activities were $0.390,0.450$, and $0.500 \mathrm{U} / \mathrm{ml}$ with using of 1,2 , and 4 mycelail plugs respectively (Fig. 3).

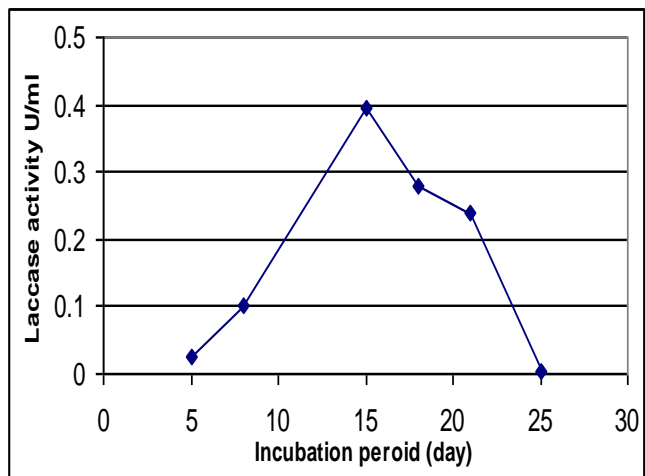

Fig 2: Effect of incubation period (day) in laccase production by Pleurotus ostreatus on humidified sawdust medium.

The enzyme yield has been reduced at lower and higher inoculum levels. A very low inoculum size was found to be inadequate for enzyme production while the inoculums above optimum level cause lowering in the yield probably due to the competition for nutrients.

In previous studies different inoculms size have been used for laccase production, four p. pulmonarius mycelial plugs measuring $10 \mathrm{~mm}$ in diameter were used for inoculation of $5 \mathrm{~g}$ of wheat bran, results showed higher laccase activity reached up to $8.600 \mathrm{U} / g$ substrate [7], while [19] have been used three $T$. hirsute agar plugs (diam., $3 \mathrm{~mm}$ ) for inoculated $2.5 \mathrm{~g}$ barley bran or $5 \mathrm{~g}$ grape seeds.

Among various substrates (wheat straw, corncobs, coconut coir, wheat bran, and rice bran) inoculated with five agar plugs $(8 \mathrm{~mm})$ of white-rot fungi. Highest level of laccase production was observed with $P$. ostreatus at $8^{\text {th }}$ day of fermentation using wheat straw as substrate [17]. Recent study with $F$. incarnatum LD3, four mycelial agar plugs of $8 \mathrm{~mm}$ in diameter for inoculation of $5 \mathrm{~g}$ wheat straw was used; laccase production was increased from $40 \mathrm{U} / \mathrm{g}$ to $650 \mathrm{U} / \mathrm{g}$ of substrate [20]. 


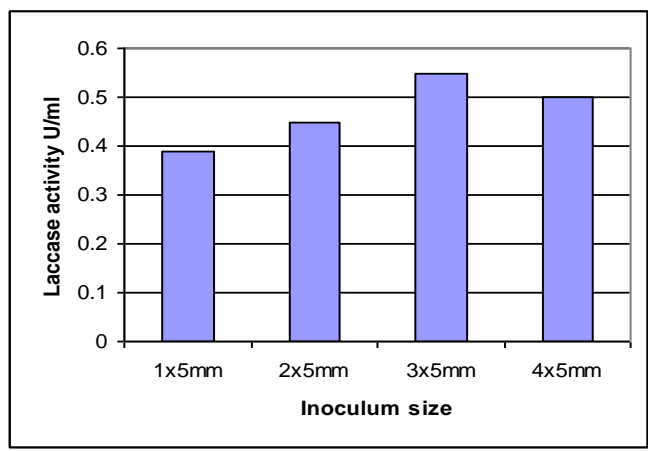

Fig. 3: Effect of inoculum size $(5 \mathrm{~mm}$ mycelial plug) in laccase production by Pleurotus ostreatus on humidified sawdust medium.

\section{Effect of incubation temperature on} $P$. ostreatus laccase production:

Temperature is much significance in the SSF systems because during fermentation there is a general increase in the temperature of the fermenting mass due to respiration [22]. Even though the impact of temperature is more prominent in the scale up processes it remains an inevitable factor in all fermentation systems due to its impact on microbial growth and metabolite production. Results of the present study (Fig. 4) suggested that an incubation temperature of $25^{\circ} \mathrm{C}$ was the optimum for laccase production $(0.69 \mathrm{U} / \mathrm{ml})$ and considerable specific activity was observed (69 U/mg) (results are not shown).

Although, the effect of temperature on the growth of $P$. ostreatus as well as laccase production by this organism has been studied extensively in earlier work [18], and it can be concluded that temperature exerts a similar effect on growth and enzyme production despite of the mode of fermentation. The data on effect of $\mathrm{pH}$ and temperature on laccase production was scarce, but most reports indicated that the initial $\mathrm{pH}$ between 4.5 and 6.0 was suitable for enzyme production [23]. [24] pointed that the optimum temperature for laccase production was between $25^{\circ} \mathrm{C}$ and $30^{\circ} \mathrm{C}$, while the activity of laccase reduced when fungi were cultivated at temperatures higher than $30{ }^{\circ} \mathrm{C}$ the [25].

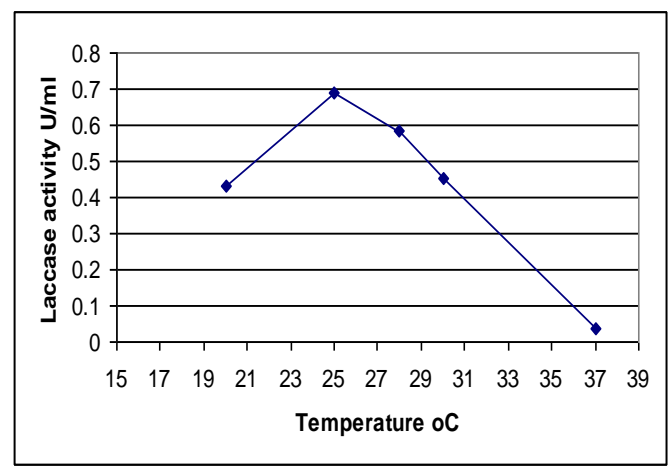

Fig. 4: Effect of incubation temperature in laccase production by Pleurotus ostreatus on humidified sawdust medium.

\section{Degradation of phenol by crud laccase:}

Phenol degradation by crud laccase has been investigated using enzyme filtrate with activity $0.55 \mathrm{U} / \mathrm{ml}$. The reaction mixture contains $1 \mathrm{ml}$ enzyme and $2 \mathrm{ml}$ phenol in citrate-phosphate buffer $(0.1 \mathrm{M}, \mathrm{pH}, 5.6)$ at different concentrations. The reaction carried out in shaking incubator at $25^{\circ} \mathrm{C}$. About $50 \%$ of phenol was degrading after $4 \mathrm{hrs}$ of incubation at all concentrations (Tab. 2), and $100 \%$ of phenol was degrading after $24 \mathrm{hr}$ except at $200 \mathrm{~g} / \mathrm{l}$, the remaining phenol was $10.13 \%$.

Laccase is blue oxidase capable to oxidizing phenols and aromatic amines by reducing molecular oxygen to water by multicopper system [26]. Continuous elimination of 2,6dimethoxyphenol by immobilized laccase has been carried out in a packed bed reactor. Gas chromatographical analysis showed that there was no 2,6-dimethoxyphenol dissolved in the filtrate after $20 \mathrm{hr}$ [27]. 
Table 2: Degradation (\%) of phenol by crud laccase after different incubation time at $25 \circ C$ using shaking water bath.

\begin{tabular}{|c|c|c|c|c|c|}
\hline $\begin{array}{c}\text { Phenol con. } \\
\text { mg/l }\end{array}$ & \multicolumn{5}{|c|}{ phenol degradation (\%) } \\
\hline $\begin{array}{c}\text { Incubation } \\
\text { time (hr) }\end{array}$ & $\begin{array}{c}\text { Zero } \\
\text { time }\end{array}$ & $\mathbf{2}$ & $\mathbf{4}$ & $\mathbf{6}$ & $\mathbf{2 4}$ \\
\hline 6.25 & 0 & 49.2 & 50.6 & 59.5 & 100 \\
\hline 12.5 & 0 & 21.3 & 51.3 & 59.8 & 100 \\
\hline 25 & 0 & 17.3 & 52.5 & 59.6 & 100 \\
\hline 50 & 0 & 15 & 52.7 & 52.7 & 100 \\
\hline 100 & 0 & 8.9 & 51.6 & 53.2 & 100 \\
\hline 200 & 0 & 4.2 & 50.2 & 54.5 & 89.87 \\
\hline
\end{tabular}

\section{References:}

1. Rosales,E., Rodr'iguez Couto, S., and Sanrom, A. 2002. New uses of food waste: application to laccase production by Trametes hirsute. Biotechnology Letters 24: 701-704.

2. Pelaez, F., Martínez, M. J., Martínez, A. T. 1995. Screening of 68 species basidiomycetes for enzymes involved in lignin degradation. Mycol. Res. 99: 37-42.

3. Vares, T. and Hatakka, A. 1997. Lignin-degrading activity and ligninolytic enzymes of different white-rot fungi: effects of manganese and malonate. Can.J.Botany, 75:61-71.

4. Pandey, A., Selvakumar, P., Soccol, CR., Nigam, P. 1999. Solid state fermentation for the production of industrial enzymes. Curr. Sci.77: 149-162.

5. Ardon, O., Kerem, Z. and Hadar, Y. 1996. Enhancement of the laccase activity in liquid cultures of the ligninolytic fungus Pleurotus ostreatus by cotton stalk extract. J.of Biotech. 51: 201-207.

6. Kahraman, S.S. and Gurdal, I.G. 2002. Effect of synthetic and natural culture media on laccase production by white rot fungi. Bioresource Technology 82: 215217.

7. Souza, C., Zilly, A. and Peralta, R. 2002. Production of laccase as the sole phenoloxidase by a Brazilian strain of Pleurotus pulmonarius in solid state fermentation. J. of Basic Microbiol. 42: 83-90.

8. Couto, S.R., Maria, G., Miriam, L. and Sanroman, M.A. 2002. Screening of supports and inducers for laccase production by Trametes versicolor in semi-solid- state conditions. Process Biochem. 38: 249-255.

9. Risna, R.A. and Suhirman 2002. Ligninolytic enzyme production by Polyporeceae from Lombok, Indonesia. Fungal Diversity 9: 123134.

10. Pottast, A., Thomas, R., Chen, C.L., and Gratzl, J.S. 1995. Selective enzymatic oxidation of aromaticmethyl groups to aldehydes. J. Org. Chem.60: 43204321.

11. Ling, S.K., 1994. Biochemical changes associated with growth of Pleurotus sajor-caju on oil palm frond parenchyma tissue. M.Sc. of Biotech. Thesis. Uni. of Malaya.

12. Mazmanci, M. A., Unyayar, A., Erkurt, E. A., Arkci, N. b., Bilen, E., and Ozyurt, M. 2009. Colour removal of textile dyes by culture extracts obtained from white-rot fungi. African J. Micro. Research, 3:585-589.

13. Leonowicz, A. and Grzywnowicz, K. 1981. Quantitative estimation of laccase forms in some white rot fungi using syringaldazine as a substrate. Enzyme icrob. Technol., 3, 55-58.

14. Bradford M. M.1976. A rapid and sensitive method for the quantitation in microgram quantities of protein utilizing the principle of protein dye binding. Ana. Biochem. 72: 248254.

15. Al-adhami, A.J.H. 2001. Use of polyphenol oxidases from wood rotting fungi for actinocin production. Ph.D. Thesis in Biotech.; Univ. of WrocLaw. Poland. 
16. Hölker, U., and Höfer M. 2002 Solid substrate fermentation of lignite by the coal solubilizing mould Trichoderma atroviride in a new type of bioreactor.

Biotech. Lett 24:1643-1645.

17. Gupte, A., Gupte, S., and Patel, H. 2007. Ligninolytic enzyme production under solid-state fermentation by white rot fungi. J.Scien. Indust.Reas. 66:611-614.

18. Niladeyi, K. N., Sukumaran, R.K., and Prema, P. 2007. Utilization of rice straw for laccase production by Streptomyces psammoticus in solidstate fermentation. J Ind Microbiol Biotechnol. 34:665-674

19. Moldes, D., Gallego, S., Couto, S. R., and Sanroman, A. 2003. Grape seeds:the best lignocellulosic waste to produce laccase by solid state cultures of Trametes hirsute. Biotech. Lett. 25: 491-495.

20. Chhaya, V and Gupte, A. 2010. Optimization of media components for laccase production by litter dwelling fungal isolate Fusarium incarnatum LD-3. J. Basic Microbiol, 50, 43-51

21. Machuca, A. and Ferraz, A. 2001. Hydrolytic and oxidative enzymes produced by white- and brown rot fungi during Eucalyptus grandis decay in solid medium.

Enzyme and Microbial Technology 29: 386-391.
22. Pandey A, Radhakrishnan, S. 1992. Packed bed column bioreactor for production of enzymes. Enzyme Microb Technol. 14:486-488.

23. Thurston,C. F. 1994. The structure and function of fungal laccases. Microbiology, vol. 140, no. 1, pp. 19-26.

24. Pointing, S. B., Jones, E. B. G., and Vrijmoed, L. L. P. 2000. Optimization of laccase production by Pycnoporus sanguineus in submerged liquid culture," Mycologia, vol. 92, no. 1, pp. 139144.

25. Zadrazil, F. Gonser, A., and Lang, E. 1999. Influence of incubation temperature on the secretion of extracellular lignolytic enzymes of Pleurotus and Dichomitus squalus into soil," in Proceedings of the Conference on Enzymes in the Environment, Granada, Spain.

26. Yaropolov, A. I., Skorobogatko, O. V., Vartanov, S. S., and Varfolomeyev, S. D. 1994. Laccase properties, catalytic mechanism and applicability. Appl. Biochem. Biotech. 49: 257-280.

27. Hublik G. and Schinner F. 2000. Chracterization and immobilization of laccase from Pleurotus ostreatus and its used for the continuous elimination of phenolic pollutants. Enzyme and Microb. Tech. 27: 330336. 


\section{تحديد ألظروف المثلى لأنتاج اللاكتيز من الفطر بأستخدام نشارة ألخشب كوسط صلب و لأنتاج دور ألانزيم في تفكيك الفينول}

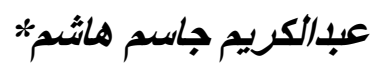

* قسم التقنية ألاحيائية / كلية العلوم / جامعة بغداد

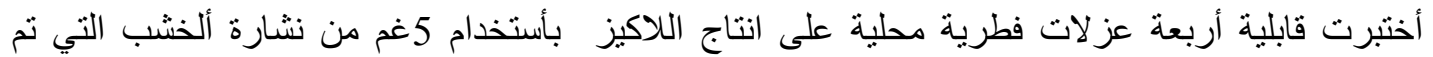

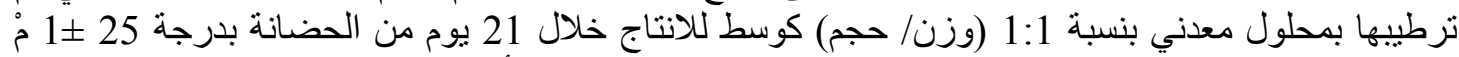

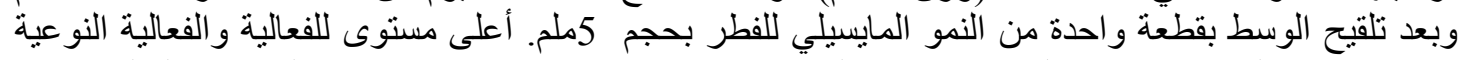

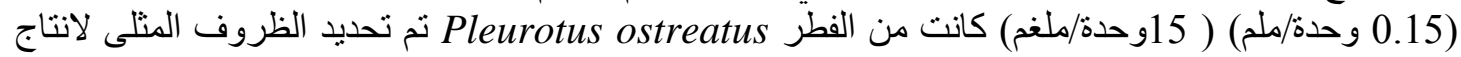

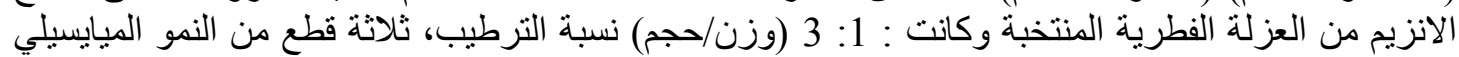

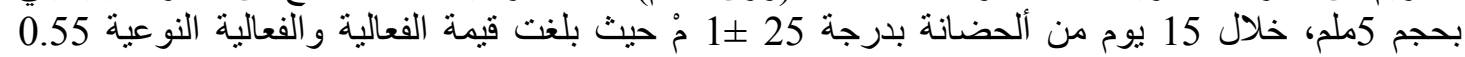
وحدة/ملم 55 وحدة/ ملغم على التو الي.

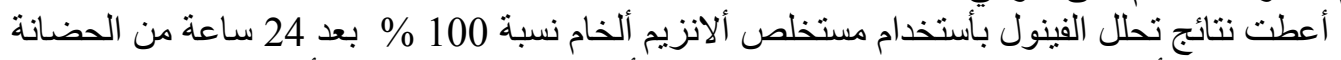

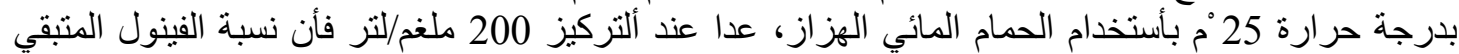
كانت .10.13 